\title{
Promoting Innovation in Food Industry Through Supply Chain Networks: Transactional or Collaborative?
}

\author{
Erni Ernawati* \\ PPM School of Management \\ Jakarta, Indonesia \\ School of Business \\ IPB University (Bogor Agricultural \\ University) \\ Bogor, Indonesia \\ ernwati@yahoo.com \\ Setiadi Djohar \\ PPM School of Management \\ Jakarta, Indonesia \\ School of Business \\ IPB University (Bogor Agricultural \\ University) \\ Bogor, Indonesia \\ sdjohar@gmail.com
}

\author{
Machfud \\ Agroindustrial Technology \\ Department \\ IPB University (Bogor Agricultural \\ University) \\ Bogor, Indonesia \\ mfd@indo.net.id
}

\author{
Idqan Fahmi \\ School of Business \\ IPB University (Bogor Agricultural \\ University) \\ Bogor, Indonesia \\ ifahmi.mk@gmail.com
}

\begin{abstract}
Innovation is also a determinant of excellence in business competition. However, innovation is often perceived as an activity that costs money, time, energy, and mind. Yet by utilizing the supply chain network owned by the company, innovation can be done more cheaply, easily, quickly, and right on target. The purpose of this study is to understand the extent of the effect of the supply chain networks owned by the company, both transactional and collaborative in the development of innovation. The innovations in this research include innovations in products, processes, marketing, and organizations. This research method uses Structural Equation Model (SEM). Data was collected from 250 processed food companies in Indonesia through questionnaires. The results showed that the supply chain network both transactional and collaborative, had a significant effect on innovation. However, the results also show that collaborative supply chain networks have a greater influence than transactional. The results suggest that business should promote more on collaborative supply chain networks than merely a transactional one to develop more innovative and competitive food industry.
\end{abstract}

Keywords: transactional supply chain networks, collaborative supply chain networks, innovation, food industry, Structural Equation Model

\section{INTRODUCTION}

Today's the organization seems to operate in a global business environment characterized by rapid changes, rapid technological advances, changes in consumer desires that are quite dynamic, and conditions of intense competition [1]. Companies in this case must be able to encourage their capacity to learn new technologies and new business practices and consistently improve organizational performance and success in the long run [2], [3].
One of the industries in Indonesia that has high innovation demands and has the characteristics as described above is the processed food industry. Data from the Ministry of Industry shows that the growth of Indonesia's food and beverage industry in the third quarter of 2018 of $10.7 \%$ outpaced economic growth in the same period of $5.17 \%$. Thus it can be understood if the food industry requires faster innovation and higher innovation demands than other industries.

Innovation as a tool to achieve competitive advantage is often seen as an expensive and resource-intensive process or associated with high risk [4]. Therefore, previous studies have tried to identify various capabilities and external resources outside of internal resources to encourage innovation.

The academic importance of this study lies in its contribution to the existing literature by linking supply chain networks with innovation. Furthermore, this study wants to answer three research questions namely how the influence of the transactional supply chain network on innovation; how does the collaborative supply chain network influence on innovation; and how the influence of transactional supply chain networks on innovation with an innovation orientation moderator.

\section{MATERIALS AND METHODS}

\section{A. Literature Review and Hypotheses Development}

Innovation critically depends on how companies absorb external knowledge or information and combine it with internal knowledge and information to develop new market offerings [5]. Whereas the knowledge, skills and resources needed for innovation are widespread, so the company's 
ability to identify, access, absorb and use it is essential for innovation [6].

\section{Supply Chain Networks}

Fostering networking with external partners widely is currently considered an important factor for the development of innovation for companies [5]. It builds networks with good supply chain partners with suppliers [7] or customers or users [8] believed to facilitate access to new knowledge and accelerate the tendency to innovate. Relationships with suppliers and customers enable the company to expand pure market transactions into long-term strategic relationships characterized by mutual trust [9].

\section{Transactional and Collaborative Supply Chain Networks}

The relationship with the supply chain partners outside the company enables the company to obtain different sources of knowledge to improve its innovation process [10]. In interacting or building relationships with supply chain partners, companies generally use both transactional and relational mechanisms [11]. Other researchers claim that supplier-buyer relations can be divided into transactional or collaborative relationships [12]. Transactional mechanisms in practice focus on efficiency in the supply chain, which is manifested in jointly stipulated contract clauses and specific investments related to bilateral transactions [13]. Meanwhile, relational or collaborative mechanisms focus on the role of social interaction and socially embedded relationships in economic activity [14].

\section{Innovation}

The development around the definition and understanding of innovation is very rapid. Innovation includes developing new products and new forms of organizational structure, opening new markets, creating new production lines and finding new sources of raw materials [15]. The classic taxonomy of innovation distinguishes innovation in products and processes [16]. Whereas innovation can be grouped into three clusters namely innovation as a result, innovation as a process and innovation as a mind-set [17].

\section{Innovation Orientation}

Innovation-oriented companies are focused on creativity and developing new ideas to achieve market success through the products and services offered, and then focus on customer satisfaction and loyalty, by developing a good impression and long-term relationship with customers, satisfying customer needs, and increase customer value based on company image [18]. Companies with an innovation-oriented organizational culture can produce more innovative products and values for their partners while looking for different approaches to innovation [19].

\section{Conceptual Framework}

Referring to the theoretical review and findings from previous studies, the conceptual framework in this study can be seen in Fig 1. The independent variables that will be used in this study are transactional supply chain network variables, collaborative supply chain network variables and innovation orientation variables. While the dependent variable that will be tested in this study is the innovation variable.

\section{Hypothesis}

Supply chain partners in general contribute more to incremental innovations [20]. Collaborative relationships with supply chain partners enable the company to respond quickly to changes in customer needs and demands [21]. Based on the conceptual framework that had been built and the findings of previous research above, the hypotheses developed in this study were as follows:

H1: Transactional supply chain networks significantly influence innovation

H2: Collaborative supply chain networks significantly influence innovation

H3: Transactional supply chain networks significantly influence innovation with an innovation orientation moderator

\section{B. Research Method}

\section{Research Design}

The design of this study used a quantitative approach, namely explanatory research in the category of confirmatory research. The confirmatory research was to prove or confirm the causal relationship between all variables to be tested, in accordance with the research framework that had been built. The variables were the innovation variable (INV) as the dependent variable, and three independent variables, namely the transactional supply chain (TSCN) variable, the collaborative supply chain variable $(\mathrm{CSCN})$, and the innovation orientation variable (IO).

\section{Analysis Unit and Research Object}

The unit of analysis in this study was the decision makers in processed food companies, specifically those responsible for activities within the scope of Supply Chain Management and primarily have access to managing chain partners. While the chosen research object in this study was a medium-scale processed food company operating in the island of Java. The method of sampling companies and respondents used a non-probability sampling approach, namely purposive sampling. This purposive sampling technique was chosen based on consideration of the availability of access in data collection.

\section{Data Collection Technique}

The primary data collection was done through in-depth interviews with selected respondents and the distribution of 300 questionnaires through surveys. A total of 250 questionnaires were collected. Related to the need for distributing questionnaires to respondents, the 30 questionnaires was first tested to ensure the validity and reliability requirements of the questionnaire.

\section{Data Processing Method}

Data collected were analysed using the SEM (Structural Equation Model) method with the Lisrel software tool. Through SEM, the researcher wanted to confirm the developed research model, which means to ensure that the structure of causality chosen or the theory used can explain the behaviour of the population being studied. 


\section{RESULTS}

\section{A. Overall Model Fit}

Testing the suitability of the whole model in this study was intended to evaluate the Goodness of Fit (GOF) between data and models. The suitability level of the whole model used absolute fit measures [22]. The complete GOFI results is presented in Table 1.

Based on the suitability test of the main research model as shown in Table 1, it appears that in general the research model had a good Goodness of Fit (GOF) between the data and the model. A total of 5 GOFIs (Goodness of Fit Index) were measured, all of them were good fit data. The more GOFI measurements that can be met by the model, it can be said that the better the research model is built.

The research model developed in this study can confirm the causal relationship between transactional and collaborative supply chain networks for innovation in the food industry in Indonesia. This is consistent with previous research which states that both transactional and collaborative or relational mechanisms are both important to reduce opportunism [23]. Processed food companies in Indonesia used both approaches to foster relationships with their supply partners with suppliers and customers. In general, transactional relationships were often used for lowvalue assets [24].

\section{B. Measurement Model Fit}

Testing at this stage was done by calculating the validity and reliability of each measurement model. Validity measurement was done by looking at loading factors $(>0.5)$ and $t$ value $(>1.96)$ [25]. Whereas a construct had good reliability if the value of Composite Reliability $(\mathrm{CR}>0.70)$ and the value of Variance Extracted (VE> 0.5) [39]. The complete results are presented in Table 2.

\section{Structural Model Fit}

Tests on structural models include examining the significance of estimated coefficients. In this study used a 95\% confidence level $(\alpha=0.05)$ so that the t-value of each coefficient of relationship between variables must have a value> 1.96. The complete results can be seen in Fig 2 above and the analysis of the hypotheses were presented in Table 3 .

Based on Table 3, it appears that the three hypotheses tested in this study showed significant results. Both transactional and collaborative supply chain networks show positive and significant effects on innovation, but the value of the influence of collaborative supply chain networks on innovation was greater when compared to transactional. This can be understood because the collaborative supply chain network adopted a relational mechanism in dealing with its supply chain partners, so the opportunity for innovation was greater. The characteristics of the relational mechanism were characterized by the open exchange of important information between suppliers and buyers, the broad sharing of ideas or initiatives, the process of resolving conflicts or problems that arise through joint discussion and joint participation in decision making [26]. While the orientation of innovation as a moderator of the relationship between transactional supply chain networks and innovation had a positive and significant effect. But with the orientation of innovation, the magnitude of its influence on innovation was even smaller than without the orientation of innovation as a moderator.

\section{CONCLUSION}

Transactional and collaborative supply chain networks, both showed a significant positive effect on innovation. However, collaborative supply chain networks showed a greater influence than transactional. Thus it can be concluded that if a company wants to develop its innovation, then a collaborative network with its supply chain partners must continue to be built in the long run.

\section{REFERENCES}

[1] Patnaik B, Beriha G S, Mahapatra S S, and Singh N. "Organizational learning in educational settings (technical): an Indian perspective". The Learning Organization 20 (2) 153-172, 2013

[2] Weldy T, and Gillis W. "The learning organization: variations at different organizational levels". The Learning Organization 17 (5) 455-470. 2010

[3] Argote L, and Miron-Spektor E. "Organizational learning: from experience to knowledge”. Organization Science 22 (5) 1123-1137, 2011

[4] Luzzini D, Amann M, Caniato F, Essig M, and Ronchi S. "The Path of Innovation: Purchasing and Supplier Involvement into New Prod. Dev. Industrial Marketing Mgt, 47109 - 120, 2015

[5] Chesbrough H. Open Innovation. Harvard Business School Press Boston, 2003

[6] Cohen W M, and Levinthal D A. "Absorptive capacity: a new perspective on learning and innovation", Adm. Sci. Q. 35 (1) 128152,1990

[7] Bidault F, Despres C, and Butler C. "The drivers of cooperation between buyers and supplies for product innovation". Res. Policy, 26 (7-8) 719-732, 1998

[8] Bogers M, Afuah A, and Bastian B. "User as innovators: a review, critique, and future research directions". J. Manage., 36 (4) 857-875, 2010 .

[9] Tether B. "Who co-operates for innovation, and why: an empirical analysis". Res. Policy 31 (6) 947-967, 2002

[10] Xu K, and Dong Y. "Information Gaming in Demand Collaboration and Supply Chain Performance". Journal of Business Logistics 25 (1) 121-144, 2014

[11] Poppo L, and Zenger T. "Do formal contracts and relationa governance function as substitutes or complements?". Strategic Management Journal, 23 (8) 707-725, 2002

[12] Heide J B, and John G. "Alliances in Industrial Purchasing: The Determinants of Joint Action in Buyer-Supplier Relationships". Journal of Marketing Research 27 (1) 24-36, 1990.

[13] Brown J R, Dev C S, and Lee D J. "Managing Marketing Channel Opportunism: The Efficacy of Alternative Governance Mechanisms". Journal of Marketing 64 (2) 51-65, 2000

[14] Granovetter M. "Economic action and social structure: the problem of embeddedness". American Journal of Sociology 91 (3) 481-510, 1985

[15] Schumpeter J A. Business Cycles. McGraw-Hill New York, 1939

[16] Blaug M. "A survey of the theory of process innovations". Economica 30 (117) 13-32, 1963

[17] Kahn K B. Understanding Innovation. Business Horizons 61453 460, 2018

[18] Lii P, and Kuo Fang-I. "Innovation-oriented SC Integration for Combined Competitiveness and Firm Performance". International Journal Production Economics 174142 - 155 , 2016 
[19] Autry C W, and Griffis S E. "Supply Chain Capital the Impact of Structural and Relational Linkages on Firm Execution and Innovation". Journal Business Logistic 29 (1) 153-173, 2008.

[20] Parrilli M D, and Heras H A. "STT and DUI innovation modes: scientific-technological and context-specific nuances". Res. Policy 45 (4) 747-756, 2016.

[21] Li Y, Wei Z, Zhao J, Zhang C, and Liu Y. "Ambidextrous Organizational Learning, Environmental Munificence and New Product Performance: Moderating Effect of Managerial Ties in China”. International Journal Food Economics 146 (1) 95-105, 2013

[22] Hair J F, Anderson R F, Tatham R L, and Black W C. Multivariate Data Analysis 5th Edition Prentice Hall, 1998
[23] Cannon J P, Achrol R S, and Gundlach G T. "Contracts, Norms, and Plural Form Governance”. Academy of Marketing Science 28 (2) 180-194, 2000

[24] Bunduchi R. "Trust, Power, and Transaction Costs in B2B Exchanges-A Socio-Economic Approach". Industrial Marketing Management 37 (5) $610-622,2008$

[25] Igbaria M, Zinatelli N, Cragg P, and Cavaye A L M. "Personal Computing Acceptable factors in Small Firms: A structural equation model”. MIS Quarterly September 279-299, 1997

[26] Jap S D, and Ganesan S. "Control mechanisms and the relationship life cycle: implications for safeguarding specific investments and developing commitment". Journal of Marketing Research 37 (2) 227-245, 2000.

\section{APPENDIX}

TABLE 1. GOODNESS OF Fit INDEX (ABSOLUTE FIT MEASURES).

\begin{tabular}{|c|c|c|c|c|c|}
\hline No & & GOFI & Standard & Result & Note \\
\hline 1. & & Statistic Chi-Square & the smaller & 39.86 & Good Fit \\
\hline 2. & GFI & Goodness of Fit Index & $\begin{array}{l}\bullet \\
\text { FI } \geq 0.90: \text { Good Fit } \\
.80 \leq \mathrm{GFI}<0.90: \text { Marginal Fit }\end{array}$ & 0.97 & Good Fit \\
\hline 3. & RMR & Root Mean Square Residual & Standardized RMR $\leq 0.05:$ Good Fit & 0.036 & Good Fit \\
\hline 4. & RMSEA & $\begin{array}{c}\text { Root Mean Square Error of } \\
\text { Approximation }\end{array}$ & $\begin{array}{l}\bullet \\
\text { MSEA } \leq 0.08: \text { Good Fit; } \\
\text { MSEA }<0.05: \text { Close Fit }\end{array}$ & 0.077 & Good Fit \\
\hline 5. & ECVI & $\begin{array}{c}\text { Expected Cross-Validation } \\
\text { Index }\end{array}$ & $\begin{array}{l}\text { On a single model } \rightarrow \text { ECVI values } \\
\text { are close to saturated ECVI: Good Fit }\end{array}$ & $\begin{array}{c}\text { ECVI : } 0.47 \\
\text { Sat. ECVI : } 0.44\end{array}$ & Good Fit \\
\hline
\end{tabular}

TABLE 2. MEASUREMENT ModEL FIT

\begin{tabular}{|c|c|c|c|c|c|c|c|}
\hline $\begin{array}{c}\text { Variable } \\
\text { (code) }\end{array}$ & Dimension & $\begin{array}{l}\text { Loading } \\
\text { Factors }\end{array}$ & $\begin{array}{c}\text { t- } \\
\text { value }\end{array}$ & Note & $\mathbf{C R}$ & $\mathbf{V E}$ & Note \\
\hline \multirow[t]{4}{*}{ INO } & Product Innovation (INPD) & 0.5 & 0.00 & Valid & \multirow[t]{4}{*}{0.86} & \multirow[t]{4}{*}{0.6} & \multirow[t]{4}{*}{ Reliable } \\
\hline & Process Innovation (INPS) & 0.86 & 8.39 & Valid & & & \\
\hline & Mktg. Innovation (INPM) & 0.97 & 8.58 & Valid & & & \\
\hline & Org. Innovation (INOR) & 0.75 & 7.93 & Valid & & & \\
\hline \multirow[t]{2}{*}{ TSCN } & Supplier Transactional (SUP-TSCN) & 0.83 & 14.77 & Valid & \multirow[t]{2}{*}{0.89} & \multirow[t]{2}{*}{0.8} & \multirow[t]{2}{*}{ Reliable } \\
\hline & Customer Transactional (CUS-TSCN) & 0.95 & 17.81 & Valid & & & \\
\hline \multirow[t]{2}{*}{$\mathrm{CSCN}$} & Supplier Collaborative (SUP-CSCN) & 0.97 & 19.12 & Valid & \multirow[t]{2}{*}{0.92} & \multirow[t]{2}{*}{0.9} & \multirow[t]{2}{*}{ Reliable } \\
\hline & Customer Collaborative (CUS-CSCN) & 0.88 & 16.56 & Valid & & & \\
\hline \multirow[t]{6}{*}{ IO } & (IO 1) & 0.94 & 0.00 & Valid & \multirow[t]{6}{*}{0.89} & \multirow[t]{6}{*}{0.6} & \multirow[t]{6}{*}{ Reliable } \\
\hline & (IO 2) & 0.91 & 23.81 & Valid & & & \\
\hline & (IO 3) & 0.61 & 11.18 & Valid & & & \\
\hline & (IO 4) & 0.70 & 13.89 & Valid & & & \\
\hline & (IO 5) & 0.82 & 18.49 & Valid & & & \\
\hline & (IO 6) & 0.52 & 9.07 & Valid & & & \\
\hline
\end{tabular}

TABLE 3. HYPOTHESIS ANALYSIS.

\begin{tabular}{|c|c|c|c|c|}
\hline Hypothesis (code) & Path Line & Coefficient & t-value & Note \\
\hline H1 & TSCN $\rightarrow$ INO & 0.25 & 2.90 & $(+)$, significant \\
\hline H2 & CSCN $\rightarrow$ INO & 0.48 & 4.60 & $(+)$, significant \\
\hline H3 & $\begin{array}{c}\downarrow \\
\text { IO } \\
\end{array}$ & 0.19 & 2.60 & $(+)$, significant \\
& TSCN $\rightarrow$ INO & & & \\
\hline
\end{tabular}




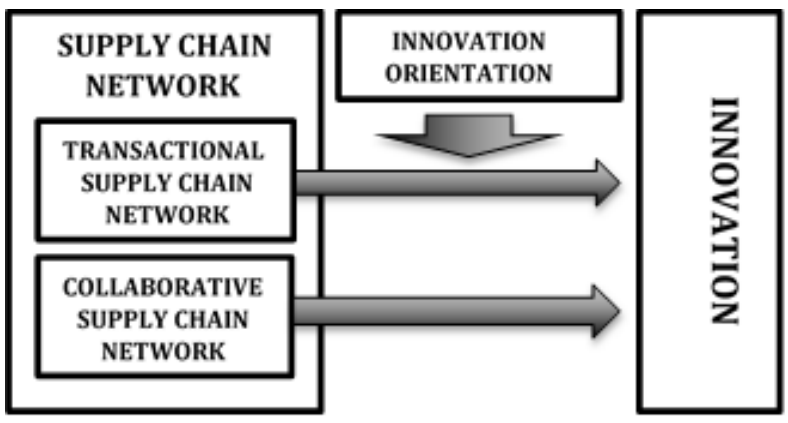

Fig 1. Conceptual Framework

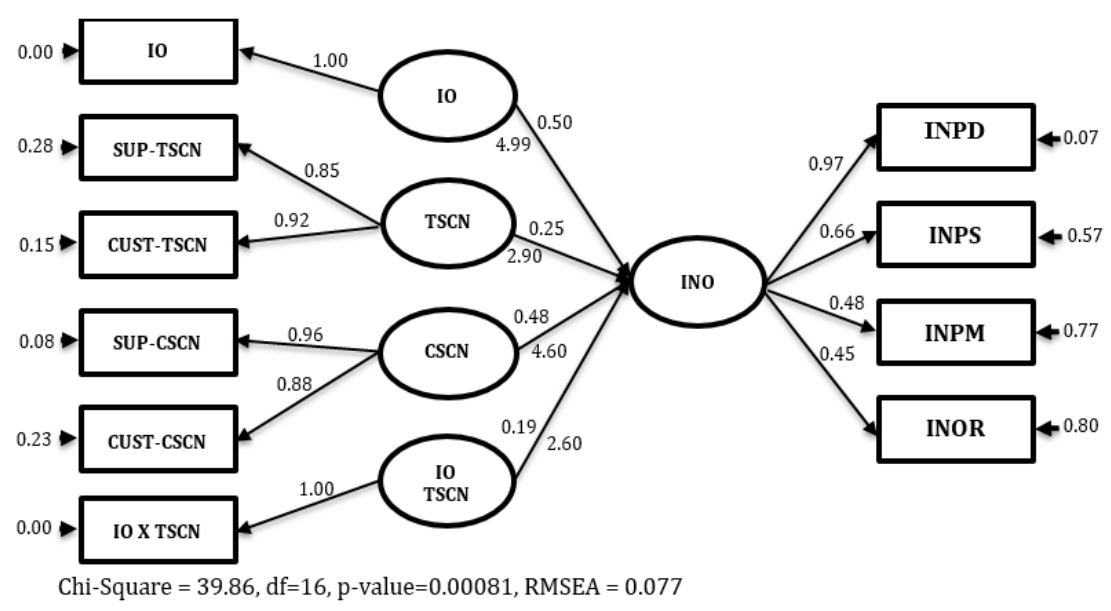

Fig 2. Structural Model Fit 